\title{
УЧЕБНИКИ РУССКОГО ЯЗЫКА ДЛЯ КИТАЙСКИХ СТУДЕНТОВ: пЛюСЫ и МИНУСЫ
}

\section{EVALUATION OF THE RUSSIAN TEXTBOOKS FOR CHINESE STUDENTS}

Li Xiaotong

Summary: The article is devoted to evaluation of basic Russian textbooks for philology students in China. In this article textbooks are studied from five perspectives, such as content comprehensiveness and scientificalness, existence of moral and cultural elements, correspondence of textbooks to the students' psychological laws of development, availability and efficiency, design and decoration, on the basis of which are summarized detailed evaluation criteria. Then we make a positive evaluation of the textbooks and point out the existing problems in them so that Russians can get acquainted with the textbooks of Russian language in China.

Keywords: Russian textbook, evaluation criteria, textbook evaluation. $\mathrm{y}$ чебно-воспитательный процесс невозможен без учебника, с помощью которого учащиеся работают как на занятиях, так и самостоятельно. Учебник знакомит учащихся с основными понятиями и категориями, содействует формированию у них мировоззрения, убеждений и поведения личности, осуществляя одновременно образовательную, воспитательную и развивающую функции.

В китайских вузах одной из обязательных и важнейших учебных дисциплин по специальности русского языка служит предмет «Практика речи» (по другому названию - интенсивное обучение русскому языку), качество учебников по которому непосредственно сказывается на успешности и эффективности учебного процесса. В нынешние дни во множестве вузов, открывающих специальность русского языка, используются «Учебники русского языка для студентов» под серией «Восток», составленные Институтом русского языка Пекинского университета иностранных языков и выпущенные Издательством преподавания и исследования иностранных языков. Учебный комплекс состоит из 8 учебников: первые 4 учебника принадлежат базовому курсу, остальные 4 - продвинутому, среди них учебники базового курса адресованы студентам, изучающим русский язык с нуля после поступления в университет, касаясь от фонетических, лексических и грамматических знаний до основных страноведений, речевых этикетов и культурной информации, глубоко влияют на результаты обучения в течение четырёх лет.

\author{
Ли Сяотун \\ Аспирант, Пекинский педагогический университет \\ 646668194@qq.com
}

Аннотация: Статья посвящена оценке учебников базового курса по русскому языку для студентов-филологов в Китае. В статье рассматриваются эти учебные материалы с таких пяти сторон, как содержательность и научность, существование моральных и культурных элементов, соответствие учебников закономерностям психологического развития студентов, доступность и эффективность, дизайн и оформление, на основе которых обобщаются подробные оценочные критерии. Далее дана позитивная оценка учебникам и одновременно указаны существующие в них недостатки, чтобы русские 0знакомились с учебниками РКИ в Китае.

Ключевые слова: учебник русского языка, оценочные критерии, оценка учебников.

Но наряду с этим, учебники русского языка базового курса были изданы лет десять назад в 2009 - 2010-ых годах, поэтому недостатки в учебниках становятся более очевидными. Таким образом, появляется необходимость анализировать и оценивать данное учебное пособие, предоставлять пригодные меры усовершенствования и повысить качество обучения русскому языку.

\section{1. Обшие стороны и конкретные критерии оченки учебников русского языка}

Оценка учебного пособия - дело непростое, требующее совмещения немалых факторов. Профессор Гао Линбяо отметил, что «При оценке учебника мы должны учитывать такие аспекты, как содержание и научность структуры, мораль и культура, познавательные и психологические правила, доступность и эффективность учебника, его уровень дизайна и оформления» [1, с. 23].

Конкретными словами, «содержание и научность структуры» касается типов знаний, отобранных в качестве учебного ресурса, и принципов организации этих знаний; «мораль и культура» учитывает роль учебника в развитии у учащихся идейной сознательности, нравственного сознания и культурной эстетики; «познавательные и психологические правила» оценивают соответствие содержания и организации учебника психологическим спецификам учащихся и их закономерностям развития познания; «доступность и эффективность» измеряет совпадение учебника с уровнем учащихся и педагогов, со средами и ресурсами университета и сте- 
пень достижения поставленных учебником целей на практике; «уровень дизайн и оформления» имеет в виду функции картин, таблиц и т.п. в понимании содержания текста, формат учебников и их качество типографии.

Между прочим, по словам китайского педагога Хоу Цяньвэя, «Оценка учебников должна лежать на основе рациональных и надёжных оценочных критериев, которые беспременно помогут дать учебникам объективную и эффективную оценку» [2, с. 61]. Критерий, это «признак, на основании которого производятся оценка, определение или классификация чего-либо»[3]. Обдумывая практическое состояние изучения и обучения русскому языку в Китае, мы устанавливаем конкретные критерии оценки учебников на основе вышесказанных сторон измерения.

В сторону «содержание и научность» мы включаем критерии «всесторонность информации» «правильность и научность языковых знаний» «современность содержания в учебниках» и «применимость языковых материалов в реальной жизни». Со стороной «мораль и культура» связаны «наличие в учебниках содержания, развивающего у студентов положительные качества, в том числе патриотизм, сознание охраны окружающей среды и т.д.» «способность учебников в демонстрировании китайской, русской и международной прекрасной культуры на изучаемом языке» и «существование в учебниках знаний, помогающих студентам в развитии хороших способов размышления и поведения». Сторона «познавательные и психологические правила» включает в себя «системность и постепенность структуры в учебниках» «помощь учебника в самостоятельном изучении студентами русского языка» и «роль учебника в развитии у учащихся русского мышления». В сторону «доступность и эффективность» включаются критерии «соответствие учебника уровню развития преподавателей и студентов» «совпадение учебника с учебной программой» «эффективность учебника в подготовке к тесту четвёртого уровня по русскому языку (ТРЯ-4)'^. В конце концов, с учётом последней стороны «уровень дизайн и оформления» при оценке учебников русского языка мы должны использовать такие критерии, как «оригинальность обложек, доброкачественность издания и удобность формата» «обилие иллюстраций и их полезность в объяснении содержания учебника» и «ограниченные печатные ошибки». Таким образом, мы перечисляем всего 16 критериев оценки учебников базового курса по русскому языку.

\section{2. Позитивная оченка «Учебники русского языка $\triangle \wedge$ я СТУАентов»}

По выдвинутым оценочным критериям мы даём оценку данному учебному комплексу. Как важный учебный ресурс более чем в ста университетах, где есть специальность русского языка, «Учебники русского языка для студентов» базового курса серии «Восток» помогают поколениям студентов в овладении русским языком, в узнавании русской культуры и даже в экскурсии по всей России. Им, безусловно, следует поставить позитивную оценку.

Заметно, что исследованные нами учебники базового курса по русскому языку в основном соответствуют развитию социальной экономики, способствуют совершенствованию преподавания РКИ в Китае и действуют в подготовке качественных квалифицированных кадров. Конкретные положительные черты проявляются в приведённых ниже пяти сторонах:

Во-первых, в целом в учебниках всестороннее и правильное содержание, что создаёт студентам и преподавателям надёжные учебные условия. В учебниках существуют как базовые фонетические (буквы, интонационные конструкции, ударение, редукция гласных, оглушение и озвончение согласных, произношение сочетаний согласных и т.д.), лексические (общий словарь каждого учебника и послетекстовые новые слова, касающиеся разнообразных отраслей), грамматические (склонение имён существительного, прилагательного, числительного и местоимения, назначения различных предлогов, спряжение и повелительное наклонение глаголов, глаголы движения, простые и сложные предложения, причастие и деепричастие и др.) и культурные знания, так и лингвистические и речевые задания.

Во-вторых, в учебниках тексты полны моральности и культурности. Большая часть информации в текстах функционирует в формировании у студентов моральных качеств и положительного мировоззрения, как «Русский характер», «Каменный цветок», «Экзамен», «Чувство Земли» и т.д. Отражают определённые страноведческие знания посредством текстов «Времена года в России», «Ярославская Масленица», «Санкт-Петербург приглашает!», «Русская кухня», «Государственная Третьяковская галерея», «Никита Михалков», «Праздники в России», «Общие сведения о Москве», «Московское метро», «О Ю. Гагарине», «Выход в открытый космос», «Зелёный крест», «Ведущие вузы России», «Высшее образование сегодня в России» и др.

В-третьих, в учебниках базового курса все языковые

\footnotetext{
1 Тест базового уровня для филологов, организуемый Центром тестирования по русскому языку при Министерстве образования
} КНР в конце второго курса. 
знания организуются в основном по системной структуре, что отвечает психологической специфике студентов. «Важнейшим элементом учебника как системы, определяющей его особенности, является структура. Под структурой мы понимаем множество элементов и связей между ними» [4, с. 7]. Вместе разберёмся в первом учебнике, состоящем из вводной и основной частей. Вводная часть - это подробная информация о базовых фонетических, орфографических и грамматических сведениях, включая произношение и правописание букв русского алфавита, ударенный слог, редукцию гласных, интонационные конструкции, род существительного и его множественное число, спряжение глагола, простые устойчивые выражения, маленькие тексты и т.д. Основная часть представляет собой начало изучения русской речи, и создаётся по линии «фонетика - грамматика - развитие речи - речевой этикет - о России», т.е. при изучении каждого урока прежде всего нуждается в повторении фонетических правил.

В-четвёртых, учебники эффективны в формировании поведения личности и в подготовке к ТРЯ-4. В целом были составлены по Учебной программе учебники, в учебниках есть темы «книга и библиотека», где написано «Книги должны принадлежать всем», «Люблю книги с занимательным сюжетом. Такую книгу начнёшь читать и уже не оставишь, пока не прочитаешь», «Хорошую книгу интересно читать не спеша, задумываясь», «Без книг в доме - самых разных, не похожих одна на другую - нельзя вырастить по-настоящему культурного человека», что призывает молодёжи к чтению и помогает им узнать, как надо правильно читать. С помощью учебников после двухлетней учёбы студенты могут свободно общаться с носителями русского языка, правильно выражать свои мнения на изучаемом языке и успешно сдать ТРЯ-4, проверяющий базовый уровень русского языка.

В-пятых, оформление учебников качественно, способствующее восприятию студентами содержания учебников. В первую очередь, обложки учебников «Восток» базового курса, занимающие немаловажное место, оформляются отдельно синим, зелёным, оранжевым и красным видами цвета, где на фоне Храма Василия Блаженного показаны русский самовар, традиционные народные костюмы, достопримечательности в России и др., что в определённой мере интересует учащихся и педагогов. Между тем, обилие иллюстраций в учебниках создают реальную ситуацию в учебном процессе. В пример возьмём страницу 180 в первом учебнике: в части «для замены» есть словосочетания «Малый театр» и «Третьяковская галерея», в этом случае рядом приложится их фото, наглядно показывающее облик здания студентам, которые не приезжают в Россию и не смотрят их своими глазами. И стоит упомянуть, что учебники в формате в 1/16 листа: $185 \mathrm{~mm} \times 210 \mathrm{~mm} \times 15 \mathrm{~mm}$, студентам удобно нести их с собой.

\section{3. Сушествуюшие недостатки в «Учебники русского языка $\triangle \wedge я$ студентов»}

Российский педагог А.В. Щепилова отметила, что «Даже самый совершенный материал не исключает его критическую переработку» [5, с. 168], это также подходит оценке учебников по русскому языку. В связи с субъективностью работы составителей, в учебнике неизбежно существуют те или иные недостатки в самом начале его выхода в свет, которые становятся очевиднее после десятилетнего пользования.

\section{Сушествование неправильных знаний в учебниках.}

Мы подтверждаем правильность знаний в учебнике, но в действительности существуют некоторые ошибки в знаниях и информации, что в какой-то степени мешает студентам в процессе обучения.

Наглядным примером служит девятый урок четвёртого учебника, в дополнительном тексте которого под названием «Выход в открытый космос» даётся информация «18-го марта 1965 года российский космический корабль «Восток-2» поднялся в космос» и «Алексей Леонов работал в условиях открытого космоса 24 минуты», но при поиске нужного дополнительного материала мы читаем такую правильную информацию: «18-19 марта 1965 года совместно с Павлом Беляевым Леонов совершил полёт в космос в качестве второго пилота на космическом корабле «Восход-2». В ходе этого полёта Леонов совершил первый в истории космонавтики выход в открытый космос продолжительностью 12 минут 9 секунд»[6], т.е. здесь ошибки в названии корабля и продолжительности работы в открытом космосе. В принципе, таких ошибок никак не замечают студенты, на чей взгляд, то, что написано в учебнике, обязательно быть правильным. Если бы не было опытных преподавателей, студенты никогда не могли бы знать точную информацию здесь.

\section{Наличие анахроничной информации в учебниках.}

Мы живём в 21-ом веке, который полон различной информацией. Студенты в учебном процессе также часто пользуются Интернетом, чтобы найти нужную себе информацию и узнать, что происходит сейчас как в Китае, России, так и во всём мире. Учебники предоставляют современные слова, но в то же время передают и анахроничную информацию.

К примеру, посмотрим упражнение 15 шестнадцатого урока первого учебника «Вопросы и ответы по рисункам - Сколько стоит?», где показаны цены бананов, сумки, брюки и т.д., в том числе банан стоит 48 руб., брюки - 98 руб. (примерно 10 юаней), сумка - 82 руб.(при- 
мерно 8 юаней). У студентов постоянно возникает недоумение: «Это правда или нет? Разве всё в России так дёшево?» Очевидно, что здесь дана тогдашняя валюта, которая совсем не совпадает с нынешней жизнью.

\section{Отсутствие очень системной структуры в учебниках.}

В этом разделе мы пытаемся оценить системность структуры учебников путём анализа отношений между грамматическими правилами и содержаниями диалогов и текстов в одном уроке, связей между уроками в одном учебнике, а также и грамматической системы во всех четырёх учебниках базового курса по русскому языку.

Отношение между грамматикой и содержанием диалогов и текстов в одном уроке

Здесь имеется в виду, степень совпадения грамматических знаний с содержанием диалогов и текстов невысока. Приведём в пример девятый урок третьего учебника. В части грамматики предлагаются как понятие, образование и функции действительного причастия, так и придаточные предложения причины, но в диалогах и текстах вовсе нет предложений, в которых применяются новые грамматические знания.

\section{Связь между уроками в одном учебнике}

По причине того, что учебник создаётся по теме, так и возникает недостаток, что между уроками отсутствует тесной связи: этот урок о русской кухне, следующий об искусстве и театре, а третий о кино. Это вызывает ситуацию, когда студенты изучают следующую тему, они забывают активные слова, словосочетания и конструкции предыдущего урока. Иными словами, такая организация учебников тормозит эффективное повторение студентами уроков.

Грамматическая система в учебниках базового курса по русскому языку

По педагогической психологии, знания в учебнике должны организовать в соответствии с закономерностью психологического развития студентов, так что нужно составить учебники по принципу «от простого к сложному, от внешнего к внутреннему». Среди учебников русского языка «Восток» в первом учебнике всего 57 грамматических знаний, во втором 34, в третьем 24 и в четвёртом 28. Показывается неровность в численности в связи с тем, что морфологические и синтаксические знания распределяются по-разному.

Помимо этого, нет ни какой связи между несколькими грамматическими знаниями в одном уроке. Например, в шестом уроке третьего учебника в части грамматики объясняются назначения видов инфинитива глаголов и придаточные предложения условия, между которыми отсутствует заметных отношений, что мешает студентам логично и системно понять эти знания в учебном процессе.

\section{ЛИТЕРАТУРА}

1. Гао Линбяо. Оценка учебников всеобщего образования: теория и орудие. М.: Издательство народного образования. 2001. С. 332.

2. Хуо Цяньвэй, Чжан Цзэнтянь. Построение оценочных критериев учебников: функции, пути и перспективы // Современная педагогическая наука. 2019. № 8. С. 61-68.

3. Педагогический терминологический словарь. URL: https://gufo.me/dict/pedagogy_terms/Критерий (дата обращения: 20.03.2019).

4. Волчкова Т.Л. Структура и дидактические принципы построения современного школьного учебника по мировой художественной культуре // Вестник Томского государственного университета. 2007. № 295. С. 7-10.

5. Щепилова А.В. Некоторые проблемы подготовки специалиста по межкультурной коммуникации: отбор учебной литературы и оценивание компетентности. М.: НЕОЛИТ, 2017. С. 168-201.

6. Алексей Леонов. URL: https://ru.wikipedia.org/wiki/Леонов,_Алексей_Архипович (дата обращения: 10.01.2020).

7. Ши Тецян, Чжан Цзиньлань. Русский язык для студентов (1). М.: Издательство преподавания и исследования иностранных языков. 2009. с. 349.

8. Лю Сумэй. Русский язык для студентов (2). М.: Издательство преподавания и исследования иностранных языков. 2010. с. 424.

9. Хуан Мэй. Русский язык для студентов (3). М.: Издательство преподавания и исследования иностранных языков. 2010. с. 445.

10. Чжан Чаои. Русский язык для студентов (4). М.: Издательство преподавания и исследования иностранных языков. 2011. с. 280. 